\title{
Securitization Theory and the Relationship between Discourse and Context: A Study of Securitized Migration in the Canadian Press, \\ 1998-2015
}

La théorie de la sécuritisation et la relation entre discours et contexte : une étude de la sécuritisation de l'immigration dans la presse canadienne, 1998-2015

La teoría de la securitización y la relación entre el discurso y el contexto: estudio sobre la securitización de la inmigración en la prensa canadiense, 1998-2015

\section{Elsa Vigneau}

\section{(2) OpenEdition Journals}

Electronic version

URL: https://journals.openedition.org/remi/12995

DOI: 10.4000/remi.12995

ISSN: $1777-5418$

\section{Publisher}

Université de Poitiers

\section{Printed version}

Date of publication: 1 October 2019

Number of pages: 191-214

ISBN: 979-10-90426-64-1

ISSN: 0765-0752

\section{Electronic reference}

Elsa Vigneau, "Securitization Theory and the Relationship between Discourse and Context: A Study of Securitized Migration in the Canadian Press, 1998-2015", Revue européenne des migrations internationales [Online], vol. $35-n^{\circ} 1$ et 2 | 2019, Online since 01 January 2021, connection on 14 April 2022. URL: http://journals.openedition.org/remi/12995 ; DOI: https://doi.org/10.4000/remi.12995 


\section{Securitization Theory and the Relationship between Discourse and Context: A Study of Securitized Migration in the Canadian Press, 1998-2015}

\section{Elsa Vigneau ${ }^{1}$}

Securitization theory, as initially developed by the Copenhagen School of Security Studies (Waever, 1989 and 1995; Buzan et al., 1998) and subsequently reconceptualized as sociological by Balzacq (2011), elaborates the insights that fundamental distinctions can be made between a social object or condition, a political problem and a security problem, and that no object is essentially (i.e. before any social interaction) a security threat. Hence, it offers an interesting alternative to the traditional dual conception of security as both an objective (security as the absence of threat to a referent object) and subjective condition (security as the absence of fear that the object be attacked) (Wolfers, 1952: 485) and proposes an understanding of security as the result of intersubjective interactions between social agents. The security status of an object is neither predefined nor permanent, it is continually constructed by the two-way relationship between agents claiming to have authority to assert the security quality of an issue (securitizing agents) and agents determining the issue of this security move by deciding to comply to it or to reject it (audiences), in a specific context. Security rests between the agents rather than in any innate threatening quality of the object. The concept of securitization can therefore be defined as the intersubjective process, intentional or unintentional, by which an object is, through the combined effect of discourse, practices and context, constituted as a security issue requiring the prompt use of defense or control mechanisms, or, more simply, as the process by which a security problem comes into being.

Following Buzan, Waever and De Wilde (1998: 25), we understand the specific character of security as relying on three distinctive features: the existential quality of the identified threat, a sense of urgency and the necessity to undertake exceptional measures to tackle the said threat. The process of securitization can be distinguished from that of politicization, which refers to the process by which an object is acknowledged as subject to public deliberation and enters the field

1 Recent graduate from the MA in Applied Political Studies, Université de Sherbrooke, 2500 boul. de I'Université, Sherbrooke, Canada; elsa.vigneau@USherbrooke.ca 
of public policy action. Securitizing an issue is a particular way of turning it into a political problem, which involves the presence of the aforementioned criteria (survival, urgency and exception). It is simultaneously an extreme form of politicization (one that calls for a specific register of policy responses, that is, security measures, which often imply the use of force and restriction of civil liberties) and its functional opposite (Buzan et al., 1998: 23-29). Indeed, if the politicization of an issue means its opening to policy debate, its securitization implies, more often than otherwise, its withdrawal of public space by calling to different kinds of emergency actions and secrecy precautions. Security is not only a state or a feeling, it represents a distinct field of state and non-state action, administered by designated actors: armed forces, police forces, secret services, private security firms, and so on (Bigo, 2002: 75). It is a special kind of politics that allow, on the ground of urgency, the breaking of the regular rules of politics.

An object can - at a given time and place - be situated in different places on a contiguum ${ }^{2}$ ranging from non-politicized (the object is not a subject of public debate, but rather considered a technical or personal matter), to politicized (it is open to debate and invest the agenda of public policy), then securitized (it is conceived as an existential and imminent threat, requiring prompt and exceptional action) (Buzan et al., 1998: 23). Politicization and securitization are distinct processes, calling for distinct coping mechanisms. However, they are neither mutually exclusive nor linked in a linear manner; an object can simultaneously be politicized and securitized as it can be securitized without being previously politicized and de-securitized without being in return politicized (Bourbeau, 2013b). In a similar fashion, recent developments in the field (Mclnnes and Rushton, 2011: 117; Bourbeau, 2011: 42; Lupovici, 2014: 405) point to further consideration of variation in scale of securitization, which can vary in intensity over time (intra-case variation), across cases (inter-case variation) and between audiences within the same spacetime frame (multi-level securitization). Securitization is neither a finite nor irreversible state of affairs: it is a highly relational process in constant need of reaffirmation and can always be intensified or minimized. While an accumulation of security moves can accentuate the degree of securitization of an object, repeated de-securitization moves or considerable decrease in the frequency or strength of security utterances can result in its relative de-securitization. However, de-securitization, defined as the process by which securitization is reversed and an issue is moved out of the threat-defense sequence (Buzan et al., 1998: 29), is not a perfect mirror reflection of securitization. The two processes are said to be in fact asymmetrical, a circumstance that Swarts and Karakatsanis explain by a security bias in the human psyche, which makes it easier to become afraid than to return to a feeling of safety once scared (2013: 109). Securitization is hence apprehended as inducing a certain pressure toward inertia (once an object is recognized as dangerous, its security framing tends to persist in time) and, moreover, as provoking a domino effect pushing towards continual intensification.

2 The term is coined by Bourbeau $(2013,136)$ to render the non-linearity of the relationship between politization and securitization and their possible spatial and temporal overlap. In contrast, the term of continuum, while accounting for the unlimited number of levels between established stages, evokes a linear progression between these points. 
With this comes the problem of the temporal unfolding of securitization: How does the securitization of an object progress over time? Providing that it intensifies, does it follow a linear trend? This question is intimately linked to an important theoretical debate of securitization literature: that of the underlying driving logic of securitization (Bourbeau, 2014). It opposes those who, loyal to the framework designed by the Copenhagen School, understand securitization as following a logic of exception, which focuses on the punctual security performances of agents during key moments, to those who comprehend it as responding to a logic of routine and think security as a routine process reproduced in everyday discourse and practices. Bigo, whose work emphasis the role of security professionals and their continuous struggle to reproduce the need for their own expertise and position as providers of protection, is a strong advocate of the latter. He contends that security is not about survival nor urgency, but rather represents a mode of governmentality depending on the diffusion of a growing sense of insecurity and social unease (Bigo, 2002).

While most empirical work tends to emphasize one logic or the other, we seek to reconcile them by inscribing both logics in a sole framework. Drawing on the suggestion made by Bourbeau of a cohabitation and complementarity of the two logics, we contemplate the possibility that securitization be operating concurrently in exception and in routine. Only then, he argues, will we be able to account for elements of both continuity and change in securitization process (Bourbeau, 2014: 6).

In a preliminary assessment (Figure 1), we foresee three alternative scenarios for the temporal deployment of securitization: 1) a security discourse occurring solely in conjunction with exceptional events offering windows of opportunity for security endeavor (logic of exception), 2) a security discourse following a linear intensification trajectory (logic of routine) and 3) a middle option showing a general increase coupled with growth peaks associated with significant events. These scenarios, which attempt to visually summarize the different approaches found in the literature, are however provisional and will be revised in view of the results of this research.

Figure 1: Securitization over time
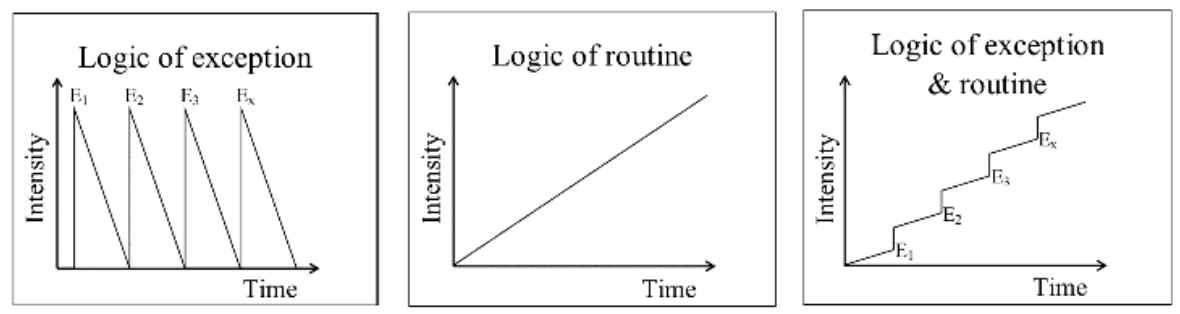

On another note, we would like to put forward a deconstruction of securitization in three analytical levels: 1) the agents, 2) their actions and 3) the context. The first level refers to who plays a role in the securitization process. It can be subdivided in two functional categories: securitizing agents and audiences. The term of "securitizing agent" designate the agent who formulates - in words or acts - a security move, asserting the danger conveyed by an object (Bourbeau, 
2013a: 23). Securitization studies have generally recognized three main types of securitizing agents: political agents, bureaucratic agents and media agents. This list is however non-exhaustive: the definition of securitizing agent heavily relies on the notions of authority and social power (Buzan et al., 1998: 31) since they impact the credibility of its move and its chances of success and remains in principle an open category. Similarly, the audience, which is responsible for the acceptance or rejection of the security move, is not a fixed entity. Its composition is defined by the internal context of the security interaction. Besides, it is multiple and can be desegregated in plural audiences depending on its current composition, be it decision-makers, security specialists, academics or the general population (Léonard and Kaunert, 2011: 61-67). We advocate here for an understanding of securitizing agent and audience as functions rather than identities. In that regard, the same individual or institution can act both as a securitizing agent and an audience, performing a security act while being currently influenced by those of other agents. For this reason, it appears little useful to try to pinpoint the sole or main responsible of securitization, let alone to understand its intentions. It is its actions rather than the agent itself which ought to be placed at the center of securitization analysis. The actions relevant in the context of securitization analysis are: the discourse or material practices of the securitizing agents and the moral or formal support of the audiences. The audience may grant (or not), explicitly or implicitly, two types of support to the security move: moral support or, if the audience is an institution with direct causal link to the proposed action, formal support (Balzacq, 2011: 9). Finally, the context in which these actions take place is constituted of events, sedimented practices, that is, practices that do not anymore pertain to the exceptional but have been integrated to the security infrastructure (Buzan et al., 1998: 205), and dominant ideas, which are understood as a diffuse set of beliefs, values and ideals that dominate and structure public thinking in a given society at a given time (Nossal et al., 2015: 135). The context is in a co-dependent relationship with the agent's actions: it facilitates or constrains the security move, but a successful security move modifies the context.

As stated above, we understand discourse, practices and context as the three equally important and mutually constituted driving components of securitization process. It is by their combined effect that securitization happens. Context plays, as reminded by Balzacq (2011) and Bourbeau (2011: 98), a fundamental role in securitization, which has been, comparatively to discourse and material practices, little explored by scholars of securitization. We consequently intend to tackle the question of the role of context in securitization by observing its interaction with discourse in the context of an original empirical study on the securitization of one peculiar issue: immigration.

The concept of securitization has been applied to a large range of objects, spanning from nuclear proliferation (Buzan, 2008: 556) to environmental degradation (Floyd, 2010) or HIVIAIDS (McInnes and Rushton, 2011). While in principle perfectly apt to study traditional (i.e. military) security issues, more often than otherwise has it been used to study how non-traditional security issues are framed as security threats (Lupovici, 2014: 401). Amongst these "new" threats, migration is one of the primary thematic focus of securitization studies. An abundant body of literature which almost represents an autonomous sub-field of securitization studies - has proliferated around the common purpose of understanding the process by which the 
movement of people across national borders is integrated into a field of practices centered on defense and control (Messina, 2014: 531; Bourbeau, 2013a: 22).

Throughout this paper, we examine the security framing of immigration in two Canadian newspapers with important readership. The Canadian case appears as particularly interesting for three reasons. First, its immigration policy has been singularly little studied in the light of securitization theory. Securitization theory being essentially European-centered regarding its academic institutionalization as much as its empirical focus (Lupovici, 2014: 391), the selection of a case external to the European continent yield strong interest in terms of empirical confrontation of theoretical developments. The consistency of European-driven conclusions with patterns observed elsewhere is indeed promising when attempting to infer a general trend. Secondly, it presents original demographic, historic and geographic features: its low population density and slowing population growth, its historical reliance, as a European colonized country, on external population influx and its relative geographical isolation, which resulted in the curious combination of a large-scale yet highly selective immigration policy. Due to geographic, economic and cultural proximity to the United States, Canada is, finally, especially likely to have been affected by the attacks of September 11, 2001, thereby permitting us to test empirically the hypothesis of a strong impact of this event on immigration representations. The extended timeframe, which covers an 18-year period, allows us to place security discourse in its broader historical context, in order to capture the ups and downs of its temporal evolution. The choice to study media discourse rather than political or bureaucratic discourse or practices is external to this article. Amid scholarly work addressing securitized migration in the Canadian context, we find certain gaps and contradictions concerning the role of media in the process. While Bourbeau, in a study of editorials published by La Presse and The Globe and Mail over the period 1989-2005, finds little to no evidences of media security moves (2011: 81-90), others have in different occasions recorded strong and frequent security utterances emanating from the Canadian press (Bauder, 2008: 289; Ibrahim, 2005: 173; Bradimore and Bauder, 2011: 647). This object has thus been chosen first and foremost to enlighten a case-specific debate related to the role played by media agents in the securitization process taking place in Canada. It however nicely serves the purposes of the present demonstration by allowing us to develop an empirical and quantitatively computable indicator of securitized migration, which facilitates comparative assessment over time. In contrast, it is rather harder to provide such indicator for material security practices, which can take various forms (e.g. legislation, international agreements, administrative directives, increase in resource allocation, stricter enforcement of existing rules), making it difficult to weight them one against the other.

While the current trend of securitizing immigration in Canada is mainly understood as having arisen in the aftermath of the Cold War as a result of growing human mobility joint to the disappearance of the bipolar superpower clash formerly structuring the global security environment (Bourbeau, 2013a: 21; Ibrahim, 2005: 167; Bigo, 2002: 77), there is also a largely shared assumption that it has been further intensified following the events of September 11, 2001 (Antonius et al., 2007; Ibrahim, 2005: 173; Messina, 2014: 531-532). However, we find in the existing literature little empirical evidence to support the claim of a lasting effect of the 9/11 attacks on the securitization of immigration. 
In another portion of our work (Vigneau, 2017), we have demonstrated that both La Presse and the National Post have contributed, by regularly including security statements in articles dealing with immigration, to construct this object as a security threat to Canada over the period 1998-2015. They have both played a part in the process of securitizing migration to Canada and can on that account be understood as securitizing agents. In this paper, we pursue the following questions: How does the security discourse of the two newspapers fluctuate over time? Is immigration increasingly depicted as posing an imminent threat to the physical well-being of the Canadian state or its population? How do the security moves of the media interact with context? Is the intensification of security discourse related to the occurrence of major migratory events? The goals of this article are thus three-fold: 1) First, it aims to produce empirical data on the saliency of security discourse on immigration in the Canadian press over an eighteen-year period. 2) Then, it investigates the strength of the relationship between major events and the frequency of security moves in the written press. 3) Finally, it intends to inform the debate between the proponents of a logic of exception and those of a logic of routine by establishing if the variations in the frequency of security discourse in La Presse and the National Post respond to exceptional impulses or rather operate in a linear way. Besides the question of context, it thus also deals with the issues of intensity and temporal unfolding of securitization.

\section{Research Design}

To achieve these goals, our first task rests in the generation of reliable data reporting on the security framing of immigration by the written press for the concerned time span. These data constitute the prime material of this empirical inquiry into securitized migration. The chief research strategy employed for this matter is that of a thematic content analysis of a set of 4,464 newspaper articles published by La Presse $(n=1,203)$ and the National Post $(n=3,261)$ on the topic of international immigration to Canada between January 1, 1998, and December 31, 2015. These articles, all available online, were located through an automated keyword search in the Eureka.cc and Canadian Newsstand search engines. The databases were searched for all news articles, editorials, columns, op-eds or letters to the editor from the two newspapers containing in their headline or lead paragraph the words "migrant", "immigrant", "immigration", "refugee", "asylum seeker", "asylum claimant", and their declensions and equivalents in French. A preliminary reading then permitted to identify and retrieve only those articles actually dealing with immigration to Canada.

The choice to include both news articles and opinion pieces directly relates to our conceptualization of the securitizing agent as a function, which urges us to avert a focus on the agent itself and its intentions for the benefits of an indiscriminate analysis of the content it produced. May its role be active (when expressing his own opinions) or passive (when relaying the words of another agent), we reckon that the media agent, when naming immigration a public safety problem and contending that it be swiftly addressed by the security apparatus of the state, acts as a securitizing agent in the immigration field, and that, thanks to its power as primary provider of information and its consequent role of selection and framing of the news. As such, it is not only the standpoints 
deliberately promoted by the newspapers that interest us, but rather the entire content published within their pages and to which the readers are exposed.

The two newspapers were selected on account of: 1) their status of national newspaper, 2) the size of their readership, 3) their geographical location, 4) their language of publication, and 5) their ideological leaning. The criterions of language and geography were deemed especially important with regards to the division of the Canadian population, and, incidentally, newspaper readership, in two major linguistic communities, which are in turn geographically segregated, with the French-speaking population mainly concentrated in the province of Quebec. La Presse is, between 1998 and 2015, the most widely read FrenchCanadian newspaper. While being mostly distributed in Quebec, the Montrealbased newspaper is available to francophone communities across Canada. It is generally regarded as close to the Liberal Party of Canada. The National Post stands as the second biggest national daily in Canada ${ }^{3}$. The conservative English-written newspaper, headquartered in Toronto (Ontario), is distributed all over Canada. Since it pertains to Postmedia Network Canada Corporation, a press conglomerate owning prominent west-located papers such as The Vancouver Sun and the Calgary Herald, it also regularly relays articles from other dailies of the network, thus reflecting, unlike La Presse which mainly embodies Francophone Quebec, the particularities of Canada's western provinces. Taken together, these two daily sheets provide an interesting overview of the divergent realities of Eastern and Western Canada, of the French-English duality and of the liberal and conservative political ideologies. The sampling period was designed to include the events of September 11, 2001, regarded by many as a major turning point in securitizing migration to the North American continent, as well as a buffer period before this event making it possible to isolate its impact. The year 1998 also marks the beginning of a period of intensive public questioning of Canada's immigration legislation, which culminates in 2001 with the passing of Bill C-11, Immigration and Refugee Protection Act, into law.

Once the corpus assembled, we proceeded with the content analysis and the coding operation at its core. Each of the articles was systematically read and searched for the presence in its midst of a security move on immigration, based on the coding instructions specified in table 1. It was then assigned a binary value, 1 when containing a security discourse and 0 when exempt of it. Following the coding instructions, an article was coded as comprising a security discourse when it either made an overt reference to physical danger or crime or to the actual or planned use of control and defense measures. The security narrative can be divided in two categories of tone: positive (when asserting that immigration is a security problem requiring the prompt adoption of security measures) and negative (when negating the danger conveyed by immigration or the necessity of security responses). Both sub-categories were however regarded as manifestations of security discourse when coding the main variable.

3 In 2015, the biggest Canadian national newspaper in terms of circulation is the Globe and Mail, with an average weekly print of 2,018,923 copies, against 1,116,647 for the National Post (News Media Canada, 2015). Initially comprised in our sample, it was finally excluded because of time constraints. Its exclusion however permitted us to respect at best the criteriums of geography, language and ideology. 
After attributing values to the whole corpus, these raw data were added up and translated into annual frequencies informing on the intensity of security narrative on immigration within the two newspapers. The computation unit is the individual article. As such, we are interested with the number of articles engaging with one peculiar depiction of immigration (immigration as a security concern), rather than in measuring the saliency of this representation within the articles.

Table 1: Coding instructions for the variable "security discourse"

\begin{tabular}{ll}
\hline I/ Is immigration addressed from a public safety perspective (i.e. as a \\
threat to the physical safety of the receiving country or its population)? \\
II/ Is the article reporting on crime involving immigrants? Is it using terms \\
pertaining to the criminal register (e.g. detention, arrest, illegality, fraud)? \\
III/ Is the article reporting on control and defense measures taken to deal \\
with immigration?
\end{tabular}

Once the database created and aggregated, we pursue our verification process by assessing the strength of the relationship between our two main variables of concern: the occurrence of major migratory events $(x)$ and the annual frequency of security discourse (y). To do so, we first perform a simple mean comparison, confronting discrepancy in frequency values for years with and without major events. We then proceed to an estimation of the impact size and persistence in time of each event, an operation allowing us to separate exceptional security moves from routinized discourse.

To assess the reliability of the coding procedure and of the resulting data, a sample of twenty articles from La Presse have been separately coded by two coders, allowing us to measure inter-coder agreement. Given the simplicity of the coded variable - a dichotomic value ( 1 or 0 ) attributed following the presence or absence of a said quality (security discourse) in the article - and the small number of observers, Krippendorff's alpha was computed in its most basic form:

$$
\alpha=1-\frac{\text { Do }}{\mathrm{De}}
$$

$D_{o}$ corresponding to the observed disagreement between the values assigned by the coders and $D_{e}$ being the expected disagreement, that is, the disagreement that would have been produced by a random attribution of values (Krippendorff, 2011). The resulting reliability coefficient was $\nabla=0.79$, which is satisfying considering the small number of articles included in the test sample. In general, a minimal score of $\otimes \geq 0.67$ is expected to consider a set of data reliable, while a result exceeding 0.80 is optimal (Krippendorff, 2004: 241). In order to ensure the uniformity of the coding operation, the current coding has also been regularly compared with the coding previously carried out to make sure that the same article be coded the same way throughout the complete categorization effort, which spanned a nine-month period. 


\section{Security Discourse in La Presse and the National Post, 1998-2015}

Security discourse, in the context of late Canadian media depiction of immigration, frame immigration as a public safety concern for Canada, that is, as a liability to the physical integrity of the state or its population, which must be dealt with by the security apparatus of the state. We understand the concept of public safety in a rather broad fashion as comprising issues of civil and national security. It however excludes the dealing with threat to non-material features of the national body such as identity. Based on the recurring themes encountered in the data, security discourse can be divided into three sub-narratives. First, it is characterized by an association between immigrant status and crime (e.g. fraud, robbery, drug trafficking, murder, war crime) or terrorism. Secondly, it manifests itself through the mention of control or defense measures taken against individual immigrants (such as arrest, detention or removal) or designed to secure immigration flow more generally, for example, security screening by the Canadian Security Intelligence Service (Bell, 2000) or carrier sanctions (Honore, 2000). At last, the security narrative comprises a public health dimension, which ranges from the voicing of worries concerning eventual diseases transported by immigrants to the proposition of mandatory detention and medical examination of all incoming migrants to protect the local population (Francis, 1999).

Figure 2 displays the main results of our data collection. It shows the annual relative frequency of security discourse in La Presse and the National Post, that is, the percentage of articles retrieved for each year that comprised a security move, computed as a simple division of the number of security-coded articles by the total number of articles for the year. For example, amongst the 328 articles of the National Post discussing international migration to Canada in 2001, 228 articles contain an expression of security discourse, which results in an annual relative frequency of security discourse of $69.5 \%$ for 2001 . We opt here for relative frequencies rather than absolute frequencies because of considerable variation in the size of our corpus over time. As a matter of fact, the National Post issues a maximum of 328 articles on the topic of Canadian immigration in 2001, against a minimum of seventy-one in 2014. The number of articles reporting on immigration in La Presse, on the other part, culminates to 133 in 2015 and drops to thirty-one in 2014. In addition, the National Post, with an average of 181 articles per year and a total of 3,261 articles, allocates more space to the topic than La Presse, which publishes an average of sixty-seven articles on immigration annually, for a total of 1,203 articles between 1998 and 2015. The display of security discourse as a proportion of total press coverage of immigration is thus essential to a comparative assessment of security discourse both over time and between the two newspapers. The graph presents three sets of results for each year: the relative frequency of security discourse measured in La Presse, that measured in the National Post, and the average frequency, which is a mean of the two previous. 
Figure 2: Annual relative frequency of security discourse, 1998-2015

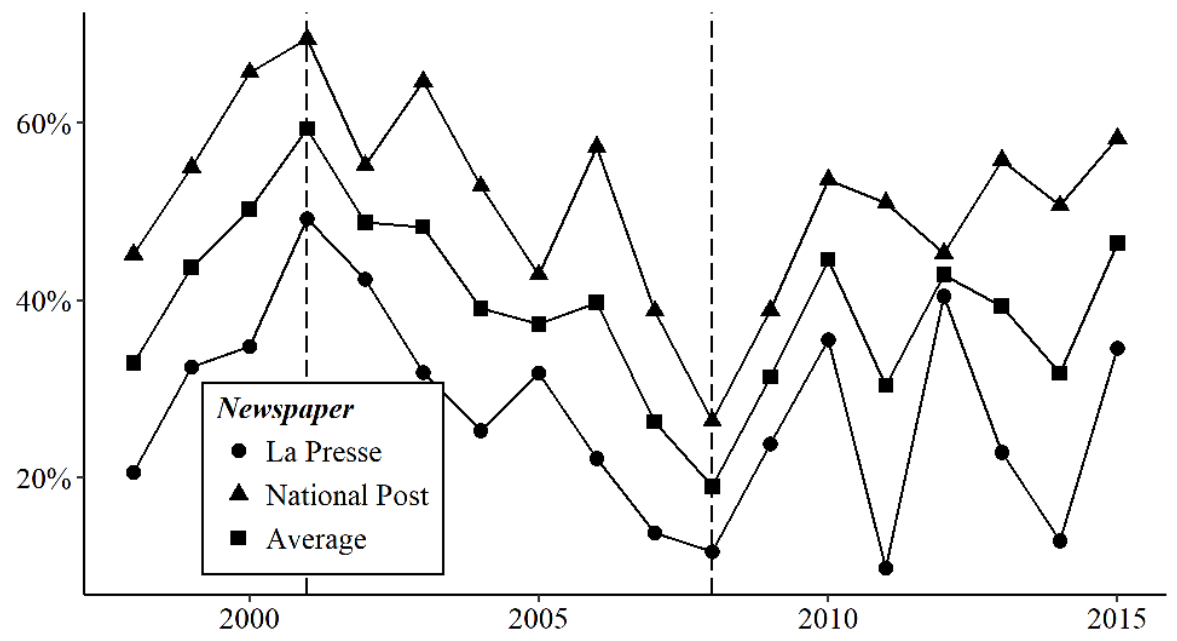

Interestingly, we observe that the two main curves (that for La Presse and that for the National Post) follow a similar temporal trajectory, sharing a correlation coefficient (Pearson's r) of 0.58 , a value expressing a strong ${ }^{4}$ and positive linear relationship between the two series. A general tendency seems to emerge, which outweighs the divergences due to individual particularities affecting news coverage (ideological leaning, institutional culture, material constraints, etc.). This convergence reinforces the relevance of hypothesizing an impact of context on discourse: the security discourse of the two dailies appears to fluctuate according to a common context, external to their editorial conditions.

However, a considerable gap persists between the two newspapers. The annual relative frequency of security discourse is on average $23.9 \%$ higher in the National Post than in La Presse. This continuous discrepancy is at its lowest in 2012 as security narrative attains a level well above average in La Presse while Bill C-31, Protecting Canada's Immigration System Act, is discussed and at its highest in 2011 and 2014 as security discourse touches unprecedent low levels in La Presse while maintaining relatively high frequencies in the National Post.

On the other hand, security discourse does not follow a linear intensification path. We were unable to observe a significant correlation between the average frequency of security narrative and the time passed. The intensity of security moves in the newspapers does not know a regular growth over this 18-year period, nor does it follow a linear decreasing trajectory. Security discourse appears more sporadic than progressive and faces an important variation over the period. At its highest level in 2001 (59.4\%), a year marked by deadly attacks on the World Trade Center and the Pentagon and by a subsequent intensification

4This qualification is based on the general markers laid down by the statistician Jacob Cohen to evaluate the strength of an effect size, which are set at $0.10,0.30$ and 0.50 for the correlation coefficient (r) of Pearson. Between 0.10 and 0.30 , the relationship is considered small, between 0.30 and 0.50 medium and strong when greater than 0.50 (Guay, 2014: 115). 
of public debate on Bill C-11, it experiences an average decline of $5 \%$ per year between 2001 and 2008 to touch its lowest point in $2008(19,1 \%)$. It then reaches new heights in 2010 (44.6\%), 2012 (42.9\%) and 2015 (46.5\%).

Similarly, the effect of September 11 on the relative frequency of security discourse on immigration appears limited in time. Indeed, while the year 2001 is singled out by a particularly high incidence of security discourse and represents the culmination of a short period of growth, the events of 9/11 do not seem to have a lasting impact on the saliency of security narrative in the press and rather initiate a period of relative decline. The event does not seem to be, as suggested by Antonius et al. (2007), Ibrahim (2005: 174) and Messina (2014), the triggering event of a renewed intensification trend of security performances. All the same, further inquiries are required to adequately assess the width of its impact. It is in this regard also important to note the high frequency of security discourse in $1999(43.8 \%)$ and $2000(50.3 \%)$, that is, prior to 9/11. After 2003, it takes seven years and the arrival on the West Coast of the MV Sun Sea, a cargo ship carrying 492 Tamil asylum seekers quickly and widely portrayed as potential members of the LiberationTigers ofTamil Eelam, an organization deemed terrorist by Ottawa, to see the average frequency of security discourse exceed in 2010 the level of 1999. New peaks are then observed in 2012, as Bill C-31 proposes to crack down on grouped irregular arrivals of refugee claimants, and in 2015, as most articles reporting on the resettlement of Syrian refugees, although generally supportive of the humanitarian merits of the initiative, express fears about possible infiltration of terrorists among the refugees and insist on the necessity of security screening.

\section{On the Relationship between Security Discourse and Events in the Canadian Press}

As justly put in by Balzacq (2011: 36), the discourse and practices of securitization do not occur in a social vacuum. On the contrary, they happen in a specific context. As such, they are both products of the current context and producers of a new context. The intersubjective relationship between the security move of a securitizing agent and its reception by its audience(s) cannot be isolated from the contextual environment in which it takes place. Amongst the three components of context earlier proposed (events, sedimented practices and dominant ideas) we retain here the one best suited for an empirical verification, that is, major migratory events. For the purpose of this research, an event is a punctual fact, circumscribed both in time and space, which attract considerable public attention. The event is intersubjectively constituted. It is the recognition by social agents of the importance of an object that makes an event (Buzan and Hansen, 2009: 55). Thus, a major event is, in the context of media coverage of Canadian immigration, an event attracting substantial media attention, the minimum threshold of which is set at ten articles dealing with the event in the two newspapers under study. For the period 1998-2015, six events meet this criterion: the Kosovar refugees' resettlement of 1999, the Chinese summer, the millennium bombing plot, the 9/11 attacks, the Tamil boats of 2009-2010 and the Syrian refugee "crisis". 
During the spring of 1999, the Yugoslavian Wars emerge as an issue of Canadian public policy as the country commits itself, on April 6, to temporarily host 5,000 Kosovar refugees. The announcement responds to an international appeal for assistance emitted by the United Nations High Commissioner for Refugees (UNHCR) following the exodus of more than a million Albanian Kosovars in Macedonia, Albania and Montenegro. On May 2, the first chartered flight lands in Canada with refugees aboard. The operation permits the resettlement of about 5,500 Kosovars over a period of four months (National Defence, 2008). It is commented in twenty-nine articles from La Presse and forty-four articles from the National Post.

The expression "Chinese summer" is used to designate the high-profile arrival of Chinese asylum seekers by sea on Canada's West Coast during the summer of 1999. Between July and September 1999, four boats carrying a total of 599 migrants from the Chinese province of Fujian are intercepted in Canadian territorial waters by the Canadian Coast Guard, the Royal Canadian Mounted Police (RCMP) and the Canadian Armed Forces. The passengers are successively arrested and taken to Esquimalt Naval Base, where they are subject to extensive security checks and held for a few weeks (La Presse, 1999a; Hasselback and Bell, 1999; La Presse, 1999b). From the 599 migrants, 577 submit an asylum application. Most are ultimately repatriated to China (National Post, 2000). The sequence of arrivals is reported in twenty-three and 101 articles from La Presse and the National Post respectively.

The arrest of Ahmed Ressam on December 14, 1999, at the Canadian-US border is another milestone of Canada's late immigration historic. The Algerian asylum seeker, intercepted in Port Angeles by an U.S. Customs officer while trying to enter the State of Washington on a ferry from Victoria (B. C.) with explosives in the trunk of his car is charged and found guilty of orchestrating a plot to blow up Los Angeles International Airport on New Year 2000 (Adelman, 2002: 7; Bell, 2001). Seven articles from La Presse and thrirty-one articles from the National Post discuss this event.

On September 11, 2001, four airliners are diverted from their course and redirected towards the two towers of the World Trade Center and the Pentagon. Resulting in a total of 2,973 deaths (9/11 Commission, 2004: 311), the event causes a shock wave and marks - according to a widely shared view - the beginning of a new era characterized by the rise of terrorism as a prime security concern in Western societies (Bigo and Walker, 2008: 13). As it appears afterwards, the suicide attack was perpetrated by a group of ninteen men who entered the US with American visas (9/11 Commission, 2004: 215-241). In the immediate aftermath of the event, however, the idea that a number of these terrorists may have transited through Canada to enter the US illegally is widely broadcasted. The hypothesis is quickly belied, but still foster a feeling of vulnerability associated to a perception of the US' northern border as porous to irregular entrances and a vector of terror risk for the US. Although not per se a migratory event for Canada, the event is widely interpreted as such. Indeed, we register eleven and forty articles explicitly dealing with the event amongst articles from La Presse and the National Post discussing Canadian immigration in 2001. 
The double arrival of the MV Ocean Lady (October 17, 2009) and the MV Sun Sea (August 13, 2010) is another major migratory event for Canada. On May 17, 2009, the civil war opposing since 1983 the Sri Lankan government and the independence insurgency of the Liberation Tigers of Tamil Eelam (LTTE) officially ends with a military defeat of the LTTE. Four months later, a ship hailing from India, the MV Ocean Lady, is intercepted by the RCMP with seventy-sixTamil Sri Lankans on board (Bell, 2009). Nearly a year later, it is followed by a second boat, the MV Sun Sea, a Thai cargo ship carrying 492 Tamil migrants (Nicoud, 2012). In sum, the two arrivals produce sixteen articles in La Presse and sixty-five in the National Post.

The 2015 Syrian refugee "crisis" refers to the major population displacements caused by the Syrian civil war and their extension to the European continent. While the "crisis" predates 2015 in many ways, it is really from 2015 on that it begins to take shape on the Canadian political and media scene. The subject becomes an issue of the federal election of October 19, 2015, as the three main political parties disagree on the number of refugees to be resettled. The Liberal Party of Justin Trudeau wins the election with the promise to welcome 25,000 Syrian refugees before the end of 2015, a target finally reached on February 29, 2016. The humanitarian effort permits - as of January 29, 2017 the resettlement in Canada of 40,081 Syrians selected by Canadian authorities in refugee camps in Turkey, Lebanon and Jordan (Government of Canada, 2017). The event attracts an important amount of media attention: eighty-nine articles from La Presse and eight-four articles from the National Post focus on the Syrian refugee "crisis" in 2015.

In short, five years show event occurrences: 1999, 2001, 2009, 2010 and 2015. While the year 1999 features three separate events, all four other years stand for one single event. When confronting the annual frequency of security discourse measured in the articles published by La Presse and the National Post on the topic of international immigration to the presence of major migratory event(s) in the year, preliminary inquiries reveal a positive link between the two variables. As intuitively foreseen when inspecting Figure 2, security discourse tends to display higher frequency on years marked by events. As it happens, the relative frequency of security discourse in La Presse is on average $35.1 \%$ for years characterized by the incidence of at least one event and $24.7 \%$ for years for which no event is registered, for a difference of 10.4 percentage points between the two groups. This difference goes down to $5 \%$ in the National Post (Figure 3). The strength of this relationship, as measured by Cohen's d, which is calculated by dividing the difference between the average value for the two groups compared (years with event(s) and years without event) by the common standard deviation $\left(\mathrm{m}^{1}-\mathrm{m}^{2} / \mathrm{sd}\right)$, is very strong for La Presse $(\mathrm{d}=0.99)$ and small for the National Post ( $\mathrm{d}=0.46)$ (Guay, 2014: 115). Events appear to have an enabling effect on the security framing of immigration by the Canadian written press, which is expected to be more important in La Presse than in the National Post. Due to a small sample size $(n=18)$, further divided in two sub-samples of five and thirteen years following the presence or not of events, these differences are however not statistically significant with $95 \%$ of confidence for the two newspapers, the $\mathrm{p}$-value being $\mathrm{p}=0.03$ for La Presse, which is satisfactory, but only $\mathrm{p}=0.2$ for the National Post. Current results for the National Post shall therefore be regarded with caution and further probed. 
Figure 3: Annual relative frequency of security discourse, mean per group

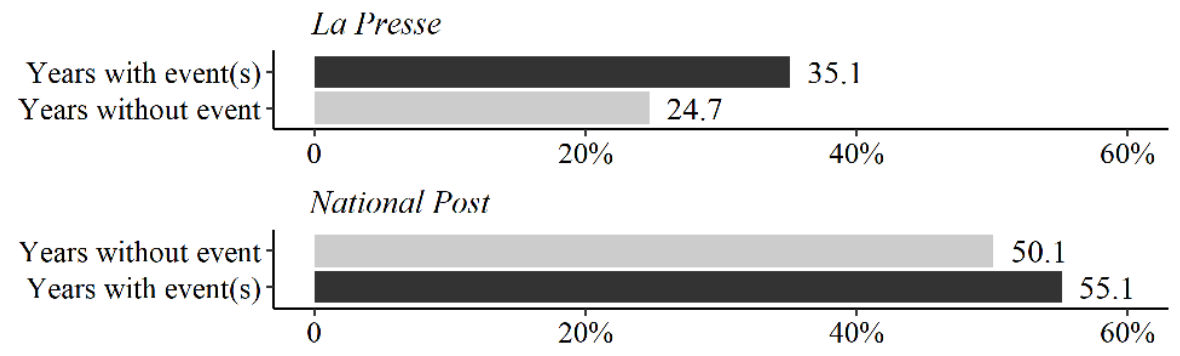

As each event may unevenly affect securitization, we then consider the differentiated impact size of the six events on security narrative. To do so, we searched our database for articles containing security discourse that were also registered as discussing one of the events. These occurrences - summed up for each event - traduce the direct impact of the event on the security performances of the press. If an article raises security concerns while reporting on a specific migratory event, we take that the two occurrences will most of the time be meaningfully related. However, this indicator does not render the indirect impact of events in the medium term, and, as such, offers an incomplete evaluation of the effect of events on security moves in La Presse and the National Post. We indeed contend that the impact of major events such as the reception of 5,500 Kosovar refugees (1999), the Chinese Summer (1999), the millennial bombing plot (1999), the 9/11 attacks (2001), the arrival of the MV Ocean Lady (2009) and MV Sun Sea (2010) and the resettlement of 25,000 Syrian refugees (2015) on the framing of immigration as a security problem is greater than the number of articles openly discussing them. These events, by catalyzing a significant portion of media and public attention toward immigration, constitute critical junctures capable of shaping both present and future perceptions of the issue, thus entailing the potential to stimulate or hinder its apprehension from a security angle. For this reason, the medium-term indirect impact of events must be taken in account. We also estimate the persistence in time of the influence of the events on the frequency of security discourse, postulating that it declines according to an exponential trajectory ${ }^{5}$. The impact of each event is, ultimately, comprised as the sum of the number of security articles explicitly dealing with the event (direct impact) and its estimated temporal persistence (indirect impact), which is calculated by applying an exponential decay function to the immediate prominence of the event. This equation takes the form $y=a^{*} \exp \left(-k^{*} t\right)$, where $a$ is the direct impact of the event at $t=0, k$ is the decay coefficient and $t$ the time passed since the event.

Once the impact of all six events computed, their respective impacts were summed up to create a single indicator: the event-driven variation. The latter was then subtracted from the observed annual frequency of security discourse

5 We concur on this matter with the "accumulated declining coverage effect" model proposed by Watt et al. to account for the exponential memory decay process of individuals in the context of agenda-setting research. Drawing on social cognitive research, they contend that the effect of media coverage on the perceived prominence of an issue decays exponentially over time (Watt et al., 1993). 
to obtain an estimation of the frequency of security discourse in the absence of event. For the current analysis, the frequency of security discourse is presented in terms of absolute frequency, which can easier relate with the absolute number of security utterances attributed to each event. Later transposition of the calculated data in percentage appear both unnecessary and potentially confusing. Figures 4 and 6 present the results of this operation, the former for La Presse and the latter for the National Post. They display three separate curves: the observed trend, the event-driven variation and the background trend, which should express routinized security discourse.

Since we aim to assess and isolate the explicative power of the logic of exception (understood as event-driven) for later gauging that of the logic of routine, we want here to maximize the hypothesis that the fluctuations in the frequency of security discourse are essentially function of events. We have therefore adjusted the persistence time of the events' impact to better match the observed curve of security discourse. For La Presse, the optimal model takes that $1 / e=2.5$, that is to say that after two and a half years, the impact of an event is reduced to $36.7 \%$ of its initial size ${ }^{6}$. For example, in addition to the thirteen security moves directly attributable to the arrival of the MV Sun Sea in 2010, it is estimated that the event also indirectly provoked 8.7 security articles in $2011,5.8$ in 2012, 3.9 in 2013, and so on.

As shown in Figure 4, the variation range of the estimated background trend for La Presse is considerably smaller than that of the observed trend, which indicates a greater data stability over time once the direct and indirect impact of the events is removed. Without event, the frequency of security discourse in La Presse would experience lower variation. While the observed trend, spanning from a minimum of four security-coded articles in 2014 to a maximum of forty-six articles in 2015 has a range of forty-two, the background trend varies between -3.5 in 2011 and 21.6 in 2012, for a total range of 25.1. The magnitude of security discourse is thus lessened to $60 \%$ of its original size. We were also able to reduce the above average frequencies of security discourse observed over the period 1999-2003 and to eliminate the peaks of 2010 and 2015, which can be comprehended as mainly event-driven and imputed to the arrival of the MV Sun Sea and to the Syrian refugee "crisis". The high points of 2007 and 2012 remain however unexplained and are to be attributed to factors other than events. The negative frequency predicted for 2011 suggests that our model slightly overestimates the durability of the impact of the Tamils' arrival. In fact, the year 2010, which features a high frequency of security discourse (twenty-one articles) is followed by a very low frequency in 2011 (six articles). Over- or underassessments of this order are however to be expected since we compute a uniform decay coefficient $(k=0.4)$ even though the effect size of each event is - as they are highly different in nature - very likely to differ. 
Figure 4: Decomposed trend, La Presse

Observed trend

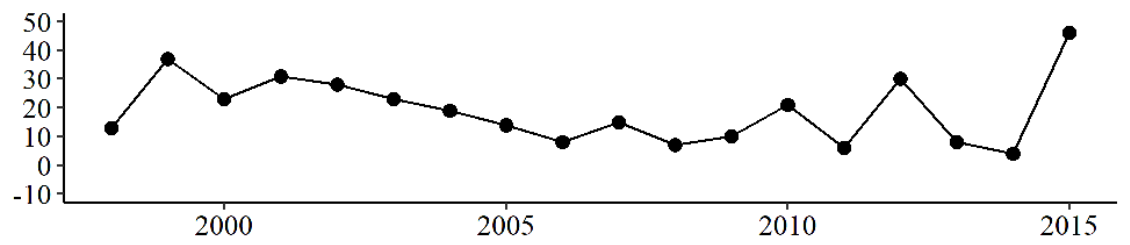

Event-driven variation

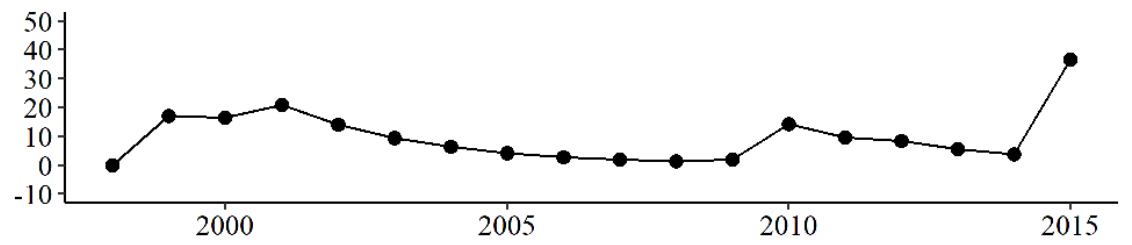

Background trend

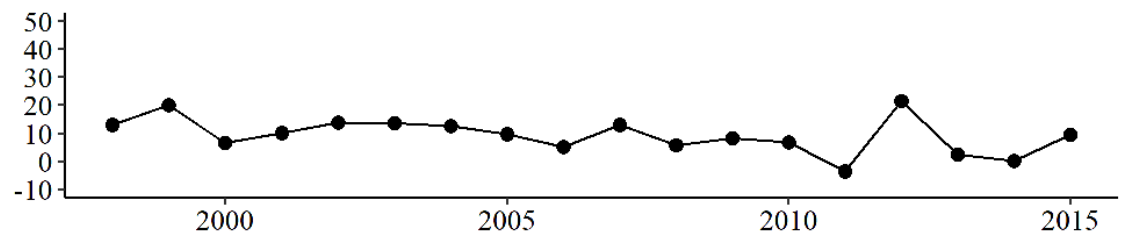

In order to evaluate the capacity of our model to explain the variation of the observed trend $(y)$ by the event-driven variation $(x)$, we then perform a simple linear regression analysis. Figure 5 offers a graphic representation of the relationship between the two variables. It also indicates the regression line, equation, and coefficient of determination $\left(R^{2}\right)$. According to this model, the impact of events would explain up to $72 \%$ of the variation of security discourse observed in La Presse.

Figure 5: Relation between event-driven variation and observed trend, La Presse

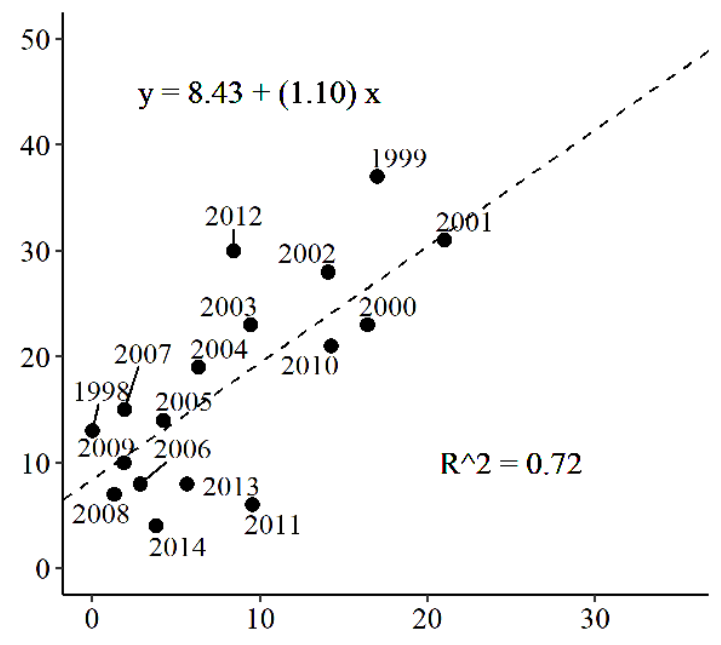


For the National Post, we must, to boost the explicative potential of events, favor a lower decay coefficient $(\mathrm{k}=0.25)$ and, accordingly, a longer persistence time, that is, $1 / e=4$. This means that an event such as the Chinese summer, producing sixty-nine security articles in the National Post in 1999, has an indirect impact of 49.7 articles in 2001, 30.1 in 2003 and 10.1 in 2007. The high frequency of security moves in 2001 (228 articles) can thus not solely be explained by the immediate effect of $9 / 11$, which generates a limited number of security articles (33 in 2001, 26.7 in 2002, 20.7 in 2003, etc.), but also by the lasting influence of the events of 1999, which, together, are taken to be responsible for 53.2 instances of security discourse in 2001.

Even after subtraction of the event-driven variation, Figure 6 reveals a background trend which remains quite irregular, with reduced yet enduring submits in 1999, 2001, 2004, 2006 and 2009. The variation range falls here from 214 for the observed trend down to 130 for the background trend, that is, to $61 \%$ of its original magnitude. This persisting variability is problematic with regards to our initial conceptualization of routinized security practice as progressive and linear (Figure 1). While the remaining peaks of 1999, 2001 and 2009 can be easily explained by a slight underestimation of the prominence of some events, which could be higher than the number of articles directly addressing them, frequencies of 2004 and 2006 are more troublesome for the hypothesis of a mainly event-driven fluctuation. This model is however apt to explain $65 \%$ of the variation in the frequency of security discourse in the National Post (Figure 7).

Figure 6: Decomposed trend, National Post
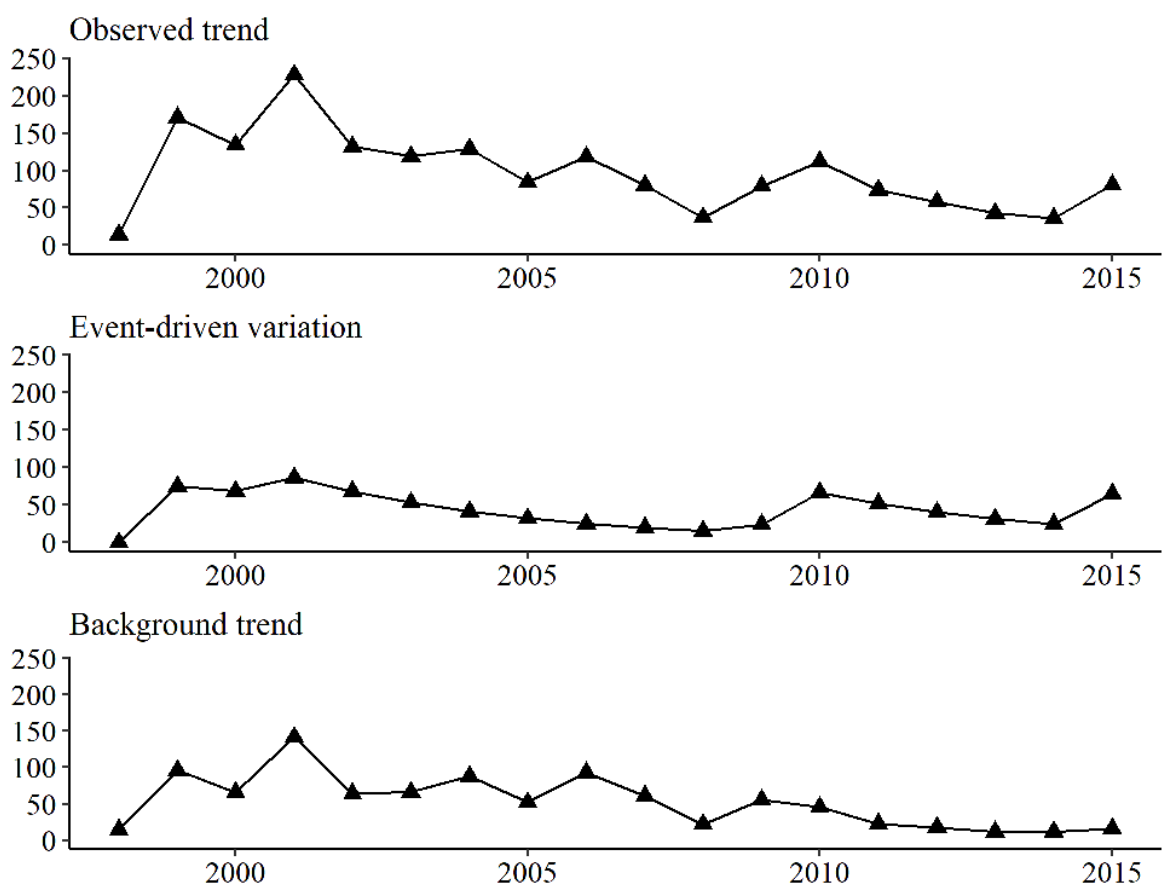
These results considerably differ from our expectations regarding routinized security discourse, which is in both cases neither linear nor following a growth trajectory (see background trend in Figures 4 and 6). They thus allow us to reject for good the hypothesis of a continuous and progressive intensification of security moves encountered many times in the Canadian and European literature on securitized migration. Furthermore, they permit us to put the impact of 9/11 on security framing of immigration into perspective. Contrary to popular views, the event did not provoke a sustained acceleration of security discourse in the press. Its impact on the frequency of security moves in the analyzed newspapers decreases rapidly. Moreover, the peak observed in 2001 in La Presse (49.2\%) as in the National Post (69.5\%) have more to do with the persistent impact of the Chinese summer of 1999 than with the direct impact of September 11.

Figure 7: Relation between event-driven variation and observed trend, National Post

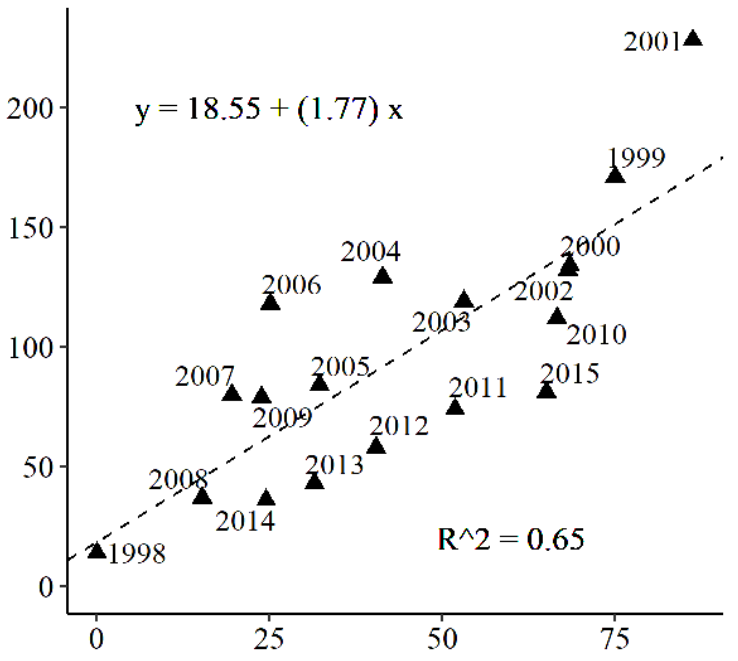

Our results also outline noteworthy disparities between the two newspapers. First, the relationship between the event-driven variation and the observed frequency of security discourse is stronger in La Presse $\left(R^{2}=0.72\right)$ than it is in the National Post $\left(\mathrm{R}^{2}=0.65\right)$. As foreseen in our first evaluation, event occurrences can more closely account for changes in the size of security framing in $\mathrm{La}$ Presse. Likewise, the number of security articles classified as not event-driven is higher for the National Post than for La Presse. Indeed, it is in La Presse 174 articles (i.e. $50.7 \%$ of the total number of security articles published between 1998 and 2015) that can be attributed to the impact of major migratory events while the remaining $169(49.3 \%)$ are imputed to everyday journalistic practices. In the National Post, 788 security articles (45.6\%) are associated with events and $941(54.4 \%)$ belong to routinized discourse. Explanations for the overall higher frequency of security discourse measured in the National Post as well as for the lower variability of security discourse between 2010 and 2015 for this newspaper can thus be found in a stronger embedment of security preoccupations into its everyday reporting on immigration. While La Presse, consistent with its liberal leaning, maintains an editorial line generally favorable to immigration, the 
National Post adopts a more critical stance toward the issue, which is illustrated by the considerable space given to polemicist journalists such as Stewart Bell and Diane Francis, who regularly advocate for reduction of immigration level.

\section{Conclusion}

Drawing on the analysis of 4,464 articles published by La Presse and the National Post about international immigration to Canada over the period 19982015, this article proposes further conceptualization of the cohabitation and complementarity of the logics of exception and routine within securitization theory and reaches the conclusion that securitization is constituted of both emergency responses and routinized practices. It reveals a high level of security discourse emanating from the press, which fluctuates importantly over time and is strongly impacted by the occurrence of major migratory events. Security discourse on immigration in the two newspapers do indeed incur quantitative intensification in the advent of events. In particular, the frequency of security moves experiences a marked increase from 1999 to 2001 under the impetus of the Chinese summer and, more marginally, of the millennium bombing plot and 9/11 events. It also reaches peaks in 2010 following the arrival on the West Coast of the MV Sun Sea, a boat carrying 492 Tamil migrants, and in 2015 in relation with the resettlement of refugees displaced by the Syrian civil war. The conjunct impact of these events can explain up to $72 \%$ and $65 \%$ of the variation in security discourse observed in La Presse and the National Post respectively. These results hence underline, on one part, the facilitating role played by events in the process of securitizing immigration to Canada and, on the other, the co-dependency of discourse and context. As it happens, the two constitutive components of securitization do not operate independently, but rather continually interact and reinforce one another.

It also demonstrates, on a more general note, the crucial role of the press in the construction of immigration in a security problem. Indeed, close to one third of the articles from La Presse and more than half of those from the National Post reported on international immigration from a public safety perspective. Doing so, the media acted as securitizing agents and participated in the production and reproduction of a security understanding of immigration.

Regarding the temporal unfolding of the process, we were unable to infer a general intensification in the security moves of the dailies. While immigration is frequently addressed as a security problem in the articles under study, we find no evidence that it is increasingly the case since 1998. This finding, which contradicts a postulate often encountered in the literature, demonstrates the relevance of quantitative assessments of securitization. We must equally quash our previous conceptualization of routinized security discourse as linear. Even after the deduction of the event-driven variation from the observed trend of security discourse, the background trend remains quite irregular. As a result, we would like to bring forward an improved version of the tripartite figure proposed above (Figure 1), that now offers an empirically-informed yet highly case-reliant formalization of the logics underlying securitization. The two logics - exception and routine - are to be understood as complementary. Henceforth, the two illustrations must be seen as two facets of a whole, which can in principle be 
isolated from one another, but in practice operate more or less simultaneously, rather than as alternative possibilities. For the current study, the security moves of the newspapers appear rather evenly distributed between exception and routine. This configuration could however vary and will have to be validated through other case studies.

In this new figure (Figure 8), the logic of exception mirrors the hypothesized exponential decreasing effect of critical junctures while the logic of routine is illustrated as irregular yet overall relatively stable, a pattern consistent with the thesis of a relatively advanced stage of securitization. The process - initiated at the beginning of the twentieth century (Messina, 2014: 538) but really reaching considerable height since 1989 (Bourbeau, 2011: 1) - now appears to be irregular but permanent. It is no longer in an emergence phase. Security, in Canada, has been successfully integrated into the everyday discourse on immigrants. In this regard, the conclusions drawn for the Canadian case agree, despite differentiated historical and demographical features, with the high level of securitization of immigration observed in several European countries (Buonfino, 2004; Caviedes, 2014) and vouch for the hypothesis of a supranational securitization trend.

Figure 8: Securitization over time
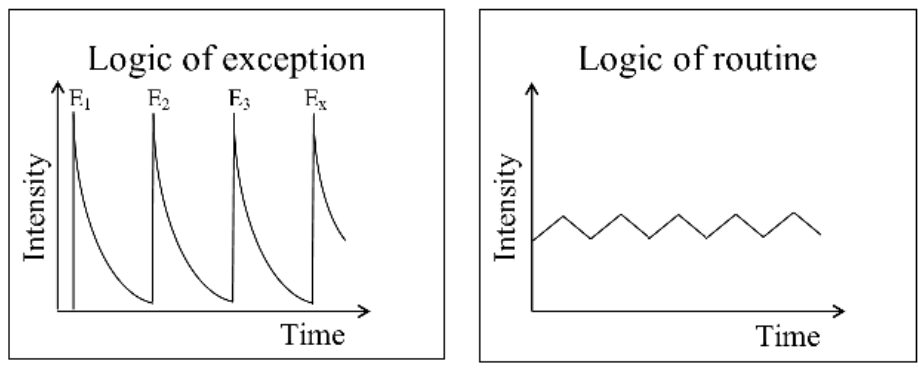

Finally, we reckon that our modelling of the impact of events on journalistic practices following an exponential decay trajectory have proven quite efficient in explaining the main high frequencies of media security discourse. However, it fails to account for some $30 \%$ of the total fluctuation of our dependent variable. The remaining variation observed in the routinized security discourse on immigration cannot be understood by the parameters included in the present study. Nevertheless, it opens the door to future research into factors apt to explain non-event fluctuations of the security moves of the press. In this regard, development of indicators reporting on the other material component of securitization process, security practices, as well as comparison of media discourse with its political and institutional counterparts could provide precious insight and contribute shedding further light on the complex and intertwined relationship between external context, discourse and practices of securitization. 


\section{References}

Adelman Howard (2002) Refugees and Border Security Post-September 11, Refuge, 20 (4), pp. 5-14.

Antonius Rachad, Labelle Micheline and Rocher François (2007) Canadian Immigration Policies: Securing a Security Paradigm?, International Journal of Canadian Studies, 1 (36), pp. 197-212.

Balzacq Thierry (2011) Securitization Theory: How security problems emerge and dissolve, New York, Routlegde, 258 p.

Bauder Harald (2008) Immigration Debate in Canada: How Newspapers Reported, 1996-2004, Journal of International Migration and Integration, 9 (3), pp. 289-310.

Bell Stewart (2009) Ship left India last month, records show: Migrant vessel: One passenger had rebel tattoo, National Post, October 23, A10.

Bell Stewart (2001) Ressam convicted of terrorism: Algerian linked to Montreal cell caught at U.S. border with powerful explosives, National Post, April 7, A1.

Bell Stewart (2000) CSIS told to improve immigrant screening, National Post, Mai 11, A8.

Bigo Didier (2002) Security and Immigration: Toward a Critique of the Governmentality of Unease, Alternatives, 27 (1), pp. 63-92.

Bigo Didier and Walker Rob B. J. (2008) Le régime de contre-terrorisme global, in Didier Bigo Éd., Au nom du 11 septembre, Paris, La Découverte, pp. 11-35.

Bourbeau Philippe (2014) Moving Forward Together: Logics of the securitization process, Millennium: Journal of International Studies, 43 (1), pp. 7-206.

Bourbeau Philippe (2013a) Processus et acteurs d'une vision sécuritaire des migrations : le cas du Canada, Revue Européenne des Migrations Internationales, 29 (4), pp. 21-41.

Bourbeau Philippe (2013b) Politisation et sécuritisation des migrations internationales : une relation à définir, Critique internationale, 4 (61), pp. 127-145.

Bourbeau Philippe (2011) The Securitization of Migration: A study of movement and order, New York, Routledge, $166 \mathrm{p}$.

Bradimore Ashley and Bauder Harald (2011) Mystery Ships and Risky Boat People: Tamil Refugee Migration in the Newsprint Media, Canadian Journal of Communication, 36 (4), pp. 637-661.

Buonfino Alessandra (2004) Between unity and plurality: the politicization and securitization of the discourse of immigration in Europe, New Political Science, $26(1)$, pp. 23-49.

Buzan Barry (2008) The Changing Agenda of Military Security, in Hans Günter Brauch et al. Eds., Globalization and Environmental Challenges, Berlin, Springer, pp. 553-560.

Buzan Barry and Hansen Lene (2009) The Evolution of International Security Studies, Cambridge, Cambridge University Press, $384 \mathrm{p}$.

Buzan Barry, Waever Ole and De Wilde Jaap (1998) Security: A New Framework for Analysis, London, Lynne Rienner Publishers, 239 p. 
Caviedes Alexander (2014) An Emerging "European" New Portrayal of Immigration, Journal of Ethnic and Migration Studies, 41 (6), pp. 897-917.

Floyd Rita (2010) Security and the Environment: Securitisation Theory and US Environmental Security Policy, Cambridge, Cambridge University Press, 215 p.

Francis Diane (1999) These refugees and immigrants can be deadly: Adequate medical screening process doesn't exist, National Post, August 21, D3.

Government of Canada (2017) \#WelcomeRefugees: Key figures, [online] last checked on 26/01/2018. URL: https://www.canada.ca/en/immigration-refugeescitizenship/services/refugees/welcome-syrian-refugees/key-figures.html

Guay Jean-Herman (2014) Statistiques en sciences humaines avec R, Québec, Presses de I'Université Laval, 238 p.

Hasselback Drew and Bell Stewart (1999) "Rustbucket" ship ferries 190 migrants from China: Third smuggling vessel to arrive this summer, National Post, September 1, A1.

Honore Carl (2000) Airlines weeding out illegals: Surrogate border guards Series: Underground to Canada, National Post, March 31, A8.

Ibrahim Maggie (2005) The Securitization of Migration: A Racial Discourse, International Migration, 43 (5), pp. 164-187.

Krippendorff Klaus (2011) Computing Krippendorff's Alpha-Reliability, [online] last checked on 25/01/2018. URL: http://repository.upenn.edu/asc_papers/43/

Krippendorff Klaus (2004) Reliability in Content Analysis: Some Common Misconceptions and Recommendations, Human Communication Research, 30 (3), pp. 411-433.

La Presse (1999a) Les immigrants illégaux ont voyagé dans des conditions cauchemardesques, La Presse, July 22, A9.

La Presse (1999b) Un autre navire d'immigrants illégaux, La Presse, September 11, B9.

Léonard Sarah and Kaunert Christian (2011) Reconceptualizing the audience in securitization theory, in Thierry Balzacq Ed., Securitization Theory: How security problems emerge and dissolve, New York, Routledge, pp. 57-76.

Lupovici Amir (2014) The Limits of Securitization Theory: Observational Criticism and the Curious Absence of Israel, International Studies Review, 16 (3), pp. 390-410.

McInnes Colin and Rushton Simon (2011) HIV/AIDS and securitization theory, European Journal of International Relations, 19 (1), pp. 115-138.

Messina Anthony M. (2015) Securitizing Immigration in the Age of Terror, World Politics, 66 (3), pp. 530-559.

National Defence (2008) Details/Information for Canadian Forces (CF) Operation PARASOL, [online] last checked on 26/01/2018. URL: http://www.cmp-cpm.forces. gc.ca/dhh-dhp/od-bdo/di-ri-eng. asp?intlopid=196\&cdnopid=236

National Post (2000) British Columbia: Chinese migrants deported, National Post, October 14, A4. 
News Media Canada (2015) Daily Newspaper Circulation Report, [online] last checked on 26/01/2018. URL: https://nmc-mic.ca/about-newspapers/circulation/ daily-newspapers/

Nicoud Annabelle (2012) Le cauchemar des réfugiés tamouls, La Presse, February 6, A2.

Nossal Kim Richard, Roussel Stéphane and Paquin Stéphane (2015) The Politics of Canadian Foreign Policy, Kingston, Queen's University Press, 424 p.

Swarts Jonathan and Karakatsanis Neovi M. (2013) Challenge to Desecuritizing Migration in Greece, Journal of Balkan and Near Eastern Studies, 15 (1), pp. $97-120$.

Vigneau Elsa (2017) Immigration et sécuritisation au Canada : étude de La Presse et du National Post, 1998-2015, MA, Université de Sherbrooke, 147 p.

Waever Ole (1995) Securitization and Desecuritization, in Ronnie D. Lipschutz Ed., On Security, New York, Columbia University Press, pp. 46-86.

Waever Ole (1989) Security, the Speech Act: Analysing the Politics of a Word, Centre of Peace and Conflict Research, Draft Paper, $56 \mathrm{p}$.

Watt James, Mazza May and Snyder Leslie (1993) Agenda-Setting Effects of Television News Coverage and the Effects Decay Curve, Communication Research, 20 (3), pp. 408-435.

Wolfers Arnold (1952) "National Security" as an Ambiguous Symbol, Political Science Quarterly, 67 (4), pp. 481-502.

9/11 Commission (2004) The 9/11 Commission Report: Final Report of the National Commission on Terrorist Attacks Upon the Unites States, 567 p. 


\section{Elsa Vigneau}

\section{Securitization Theory and the Relationship between Discourse and Context: A Study of Securitized Migration in the Canadian Press, 1998-2015}

This article addresses the problem of the significance of empirical variation in security moves towards immigration and the consequent question of the role of context in securitization theory. Drawing on the analysis of a set of 4,464 newspaper articles published by La Presse and the National Post on the subject of international immigration to Canada between January 1, 1998, and December 31, 2015, it investigates the link between the frequency with which these two Canadian broadsheet dailies depict immigration as a threat to the physical well-being of the state or its population and the occurrence of six major migratory events. It finds that the saliency of security discourse on immigration in the written press is strongly and positively impacted by the incidence of such events. The paper also proposes further conceptualization of the cohabitation and complementarity between exceptional and routinized securitization practices.

\section{La théorie de la sécuritisation et la relation entre discours et contexte : une étude de la sécuritisation de l'immigration dans la presse canadienne, 1998-2015}

Partant de l'observation d'importantes variations empiriques dans les tentatives de sécuritisation à l'égard de l'immigration, cet article s'intéresse au rôle du contexte dans la théorie de la sécuritisation. S'appuyant sur l'analyse de 4464 articles de journaux publiés par La Presse et le National Post sur le thème de I'immigration internationale à destination du Canada entre le $1^{\text {er }}$ janvier 1998 et le 31 décembre 2015, il étudie le lien entre la fréquence avec laquelle ces deux quotidiens canadiens portraient l'immigration comme une menace pour le bien-être physique de l'État ou de sa population et l'incidence de six événements migratoires majeurs. II constate que la saillance du discours sécuritaire sur l'immigration dans la presse écrite est fortement et positivement influencée par la conjoncture événementielle. L'article propose également une conceptualisation plus poussée de la cohabitation et de la complémentarité entre les pratiques de sécuritisation exceptionnelles et routinières.

\section{La teoría de la securitización y la relación entre el discurso y el contexto: estudio sobre la securitización de la inmigración en la prensa canadiense, 1998-2015}

Este artículo aborda el problema de las importantes variaciones empíricas observadas en las tentativas de seguridad hacia la inmigración y la cuestión consiguiente del papel del contexto en la teoría de la securitización. Basándose en el análisis de un conjunto de 4.464 artículos periodísticos publicados por $\mathrm{La}$ Presse y el National Post sobre el tema de la inmigración internacional a Canadá entre el 1 de enero de 1998 y el 31 de diciembre de 2015, se investiga la relación entre la frecuencia con que estos dos periódicos canadienses describen la inmigración como una amenaza para el bienestar físico del estado o de su población y la ocurrencia de seis eventos migratorios mayores. Encuentra que la incidencia de tales eventos impacta fuerte y positivamente en la intensidad del discurso de seguridad sobre la inmigración en la prensa escrita. El papel también propone una conceptualización más avanzada de la cohabitación y complementariedad entre las prácticas de securitización excepcionales y rutinarias. 